\title{
Mysoria affinis (Herrich-Schäffer): morphological variation and synonymy (Lepidoptera, Hesperiidae, Pyrrhopyginae) ${ }^{1}$
}

\author{
Andrew D. Warren ${ }^{2} \&$ Olaf H. H. Mielke ${ }^{3}$ \\ ${ }^{1}$ Contribution number 1492 of the Departamento de Zoologia, Universidade Federal do Paraná. \\ 2 Department of Zoology, Oregon State University. Corvallis, Oregon, 97331, USA. E-mail: warrena@science.oregonstate.edu \\ ${ }^{3}$ Laboratório de Estudos de Lepidoptera Neotropical, Departamento de Zoologia, Universidade Federal do Paraná. Caixa \\ Postal 19020,81531-980 Curitiba, Paraná, Brasil. E-mail: omhesp@ufpr.br
}

\begin{abstract}
Mysoria wilsoni H.A. Freeman, 1969, is established as a new junior synonym of Mysoria affinis (HerrichSchäffer, 1869). A lectotype for Pyrrhopyga [sic] affinis Herrich-Schäffer, 1869 is designated.

KEY WORDS. Guatemala, Mexico, Neotropical, seasonality, type specimens.
\end{abstract}

RESUMO. Mysoria wilsoni H.A. Freeman, 1969 é estabelecido como um novo sinônimo junior de Mysoria affinis (Herrich-Schäffer, 1869). Um lectótipo para Pyrrhopyga [sic] affinis Herrich-Schäffer, 1869 é designado.

PALAVRAS CHAVE. Exemplares tipos, Guatemala, México, Neotropical, sazonalidade.

\begin{abstract}
The examination of type specimens of Neotropical Hesperiidae in various museums by the authors has resulted in several recent changes in the synonymy of New World species, including some Pyrrhopyginae (Austin \& Warren 2002, Mielke \& Casagrande 2002). The taxonomy of Mexican Pyrrhopyginae has become better known in recent years, at the species-level (Burns \& Janzen 2001, Austin \& WarRen 2002), genus-level (MielKe 2002), and higher levels (MIELKE 2001). But many unresolved issues remain, such as the taxonomic status of Mysoria wilsoni H.A. Freeman, 1969. This subject has been a topic of investigation for the senior author for several years, as material has been accumulated from various sites (e.g. VARGAS et al. 1996, WARREN et al. 1998). Following the study of type material of $M$. wilsoni and M. affinis (Herrich-Schäffer, 1869), as well as extensive series of specimens from throughout their ranges, now it is possible to propose the synonymy of both taxa.
\end{abstract}

\section{MATERIAL}

Specimens examined are from the following collections, with their acronyms: (AMNH) American Museum of Natural History, New York, USA; (ADW) Andrew D. Warren, Colorado, USA; (AME) Allyn Museum of Entomology, Sarasota, Florida, USA; (DZUP-OM) Departamento de Zoologia, Universidade Federal do Paraná, Coleção O. Mielke, Curitiba, Paraná, Brasil; (MZFC) Museo de Zoología, Facultad de Ciencias, Universidad Nacional Autónoma de México, México City, México (much of this material currently on loan to ADW); (TAMU) Texas A \& M University, College Station, Texas, USA.

\section{RESULTS AND DISCUSSIONS}

\section{Mysoria affinis (Herrich-Schäffer, 1869)}

Pyrrhopyga [sic] affinis Herrich-Schäffer, 1869. Corr.-Blatt zool.min. Ver. Regensburg 23: 165; Tropical America.- H.A. Freeman, 1969. Jour. Lepid. Soc. 23 (suppl. 2): 3, pl. 6, figs 3, 4 (male dorsal, ventral).

Mysoria wilsoni H.A. Freeman, 1969. Jour. Lepid. Soc. 23 (suppl. 2): 3, pl. 6, figs 1,2 (male dorsal, ventral), pl. 15, fig. 1 (genitalia male); holotype male, 23 July 1956, Mexcala, Guerrero, Mexico, K. Wilson leg.; United States National Museum [but actually deposited at the American Museum of Natural History]; new synonymy.

A syntype male of Pyrrhopyga [sic] affinis Herrich-Schäffer, 1869 (Figs 1-2), was examined and photographed by the senior author in 1979 at the "Museum für Naturkunde der Humboldt Universität", Berlin, Germany. It has the following labels: /Coll. H.-Sch./ Coll. Staudinger/ affinis, HS./ Origin./ 2:3/ affinis m./ 91/ Affinis H-Sch./. "Origin." is an abbreviation of "Original", the word used by Staudinger to say "Type". To preserve stability of nomenclature, this specimen is here designated Lectotype, and an appropriate label will be added.

The type series of $M$. wilsoni consists of the holotype and nine male paratypes; five of these are from Mexcala, collected by Wilson in July, 1956, two others also from Mexcala, but collected in August 1958 by T. Escalante, one from Taxco, Guerrero, Mexico, 10 August, 1956, Stallings \& Turner leg., and one from Mapastepec, Chiapas, Mexico, August, 1951. Since 
its description, M. wilsoni has been considered a valid species (Llorente et al. 1990, de la Maza et al. 1991, Warren 2000, Mielke in press), and has been considered an endemic component of the Mexican fauna (Luis-M. et al. 2003).

FreEman (1969) separated M. wilsoni from the very similar M. affinis (Herrich-Schäffer, 1869) based on five characters, four of them on the wings, and on apparent differences in the male genitalia. However, Freeman's concept of M. affinis is not consistent with НЕRRICH-SCHÄFFER's type specimen (the lectotype) and, furthermore, none of the characters FreEman used to differentiate the two taxa are consistent when large series of specimens are examined. Below, reasons why $M$. wilsoni should be treated as a junior synonym of $M$. affinis are discussed.

Godman \& SALVIN (1879-1901) studied only a few specimens of M. affinis in their collection, from Sinaloa (Mazatlán area) and Guerrero States, Mexico; however, they also examined HerRICH-SCHÄFFer's type of M. affinis (the same specimen designated lectotype above). They noted (p. 255): “Dr. Staudinger has kindly lent us the type of this species described by HerRICH-SCHÄFFer, and we find several specimens from our collection from various parts of Western Mexico which agree with it in all essential points, but the wings, especially the primaries, are rather more elongated and the outer margin more concave". From this statement, it is evident that Godman \& SAlvin noticed the contrast in wing shape between, at least, their Mazatlán material (Plate 73: figs 19, 20), and the type specimen of M. affinis (Figs 1-2 herein). However, since Godman $\&$ SALVIN (1879-1901) illustrated the narrow-winged form as $M$. affinis, readers could be led to believe that form represents typical M. affinis, if the text is not carefully studied. This is apparently what FreEman (1969) believed, since he illustrated the narrow-winged phenotype (p. 53, figs 3-4) in the original description of M. wilsoni as typical M. affinis; indeed, FreEman's M. affinis figures are a close match to the illustrations provided by Godman \& SALVIN of M. affinis. On the other hand, FrEeman's type of M. wilsoni is a very close match to HerRICH-SCHÄFFER's type of affinis (Figs 1-2 herein). Therefore, FreEman's concept of M. wilsoni represents typical affinis, as defined by its syntypic specimen, here designated lectotype. This makes $M$. wilsoni a junior subjetive synonym of $M$. affinis, and leaves the narrowwinged form without a name; however, as it is explained below, the narrow-winged form cannot be delineated as a distinct taxon, and does not deserve a formal name.

The morphological characters used by FrEEMAN (1969) to separate the two "taxa" do not hold up when long series of specimens are examined. Freeman's main characters used to separate the taxa were forewing width, the angle of the outer margin of the forewing, and hindwing shape. Indeed, at the extremes of variation (Figs 3-6), the two phenotypes appear abundantly different. However, all intermediates between these extremes are regularly found (Figs 7-15), and clearly show these wing characters to be unreliable in splitting series into separate taxa. Indeed, material from single localities shows great variation in these characters (e.g. Figs 7, 9, 10, material from Ahuacapán, Jalisco), though there does seem to be a seasonal pattern to the variation. All specimens examined from the months of March through June (peak of dry season), regardless of their locality, represent the variably narrow-winged phenotype. Wide-winged phenotypes are known from many of these same localities (Colima, Colima; Arteaga and Rancho "El Zorrillo", Michoacán) during the rainy season (July to October). While a few narrow-wing forms were seen from rainy season months, these are mostly from seasonally very dry localities (e.g. Mazatlán, Sinaloa), or represent random "dwarfed" specimens. The vast majority of these rainy season individuals, from July to October (the majority of our sample), are widewinged forms; note also that FreEMAN's entire series of $M$. wilsoni types are from July and August. Material from transition months (November to February) is highly variable, and is generally intermediate between the two morphological extremes. While the narrow-winged (dry season) individuals in the figures 3-15 appear to have a lighter ground color than the widewinged specimens, Mysoria specimens fade rapidly as they age in collections and in the field (compare specimens from Ahuacapán, Figs 7, 9 10), and these differences are apparently artifacts of fading.

Freeman (1969) also separated M. wilsoni from M. affinis based on the extent of the yellow marginal border on the ventral hindwing, with M. affinis possessing a wider band than $M$. wilsoni. It was found that while this trait does tend to vary with wing shape, the wide-wing phenotypes generally with reduced marginal borders, it is highly variable, and does not always correspond to wing shape (Figs 7-15).

If environmental conditions are responsible for variation in wing shape and markings in M. affinis, it would not be surprising to see the same pattern repeated in closely related species. Mysoria amra (Hewitson, 1871) is a morphologically very similar species, sharing almost exactly the same primarily western Mexican distribution as M. affinis (also barely entering Guatemala - Evans 1951). In an examination of several hundred specimens of $M$. amra (not listed), similar seasonal differences in wing shape were found, though not as extreme as seen in M. affinis. Figures 16 and 17 show June and September-October individuals of $M$. amra and figures 18 and 19 of $M$. affinis. Indeed, June individuals of $M$. amra, as illustrated, tend to have narrower, slightly more elongated wings, as compared to October specimens, approaching the variation seen in $M$. affinis. However, no significant seasonal variation was seen in M. amra in the width of colored ventral hindwing marginal borders.

Male genitalia of 15 specimens of M. affinis were examined (from Sinaloa, Jalisco, Colima, Michoacán, Guerrero and Oaxaca), representing the extremes in wing shape variation, as well as various intermediate phenotypes. No differences of any kind were observed among these specimens; the genitalia are remarkably uniform. Godman \& Salvin's (Plate 73, fig. 21) 

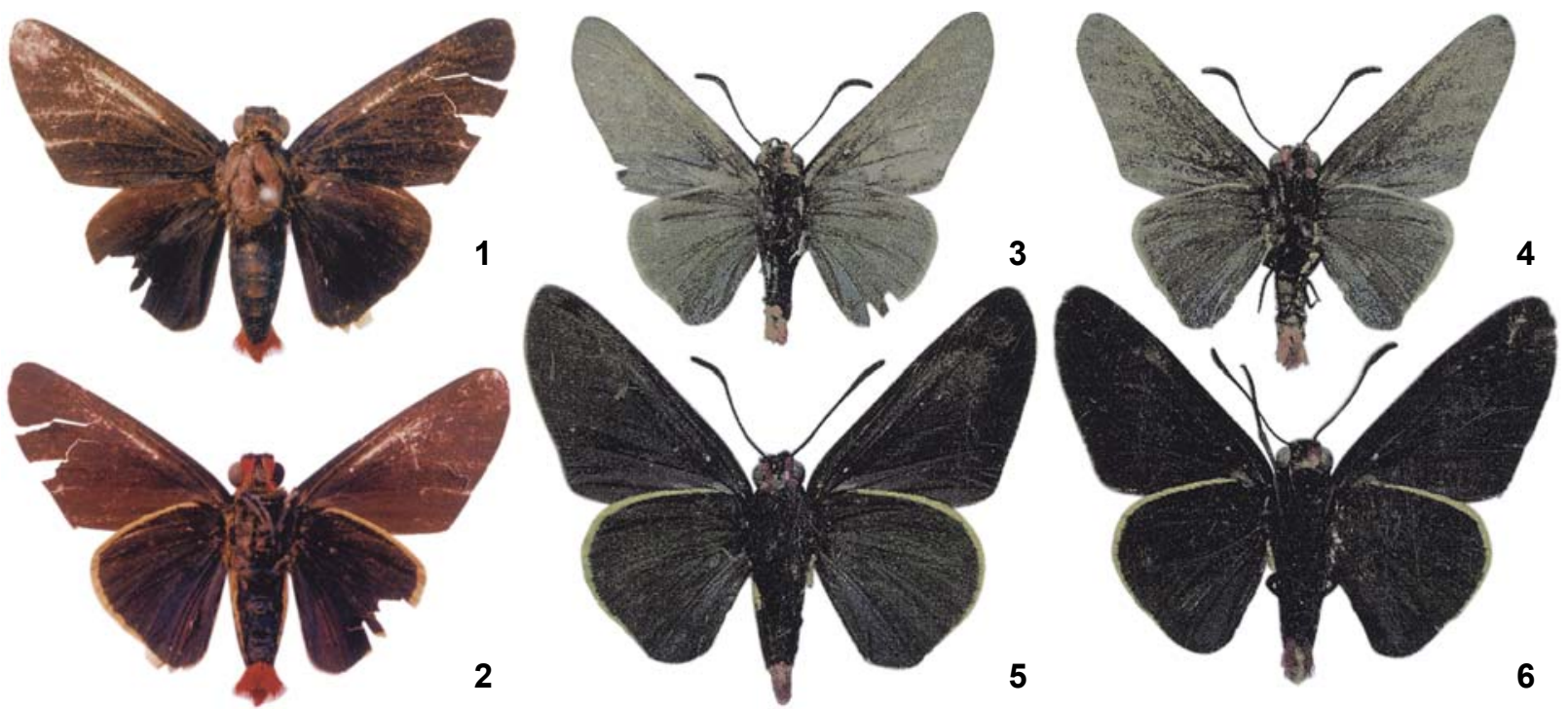

Figures 1-6. (1-2) Mysoria affinis (Herrich-Schäffer, 1869): lectotype male, dorsal (1) and ventral (2); approximately natural size. (3-6) Ventral view of narrow- and wide-winged forms of Mysoria affinis: (3) narrow-winged female, Mexıco, Jalisco: Mpio. Autlán: Ahuacapán, 900 m, 7-VI-1994 A.D. Warren leg.; (4) narrow-winged male, Mexıco, Jalisco: Mpio. Autlán: Ahuacapán, 900 m, 7-VI-1994 A.D. Warren leg.; (5) wide-winged female, Mexıco, Michoacán: Mpio. Gabriel Zamora: Barranca de Cóbano, 550 m, 3-X-1993, L. González-Cota leg.; (6) wide-winged male, Méxıco, Michoacán: Mpio. Arteaga: Hwy. 37 at Rancho "El Zorrillo", 764 m, 25-IX-1995, L. González-Cota leg.

illustration of the male genitalia of M. affinis is misleading (ventral surface of valvae not so rounded- this may be an artifact of slide-mounting); the figure by FreEMAN (1969) is more accurate, and represents the form of the genitalia seen in narrowand wide-wing phenotypes.

In conclusion, individual and seasonal variation in wing shape and pattern in Mysoria affinis is considerable, with its junior synonym $M$. wilsoni representing one extreme end of a continuous cline in wing trait variation. Male genitalia of the various forms are identical.

The broader implications of these conclusions may be significant. Evans (1951) considered forewing shape to be a valuable and informative character in many genera of Pyrrhopyginae, including Pyrrhopyge Hübner, [1819] (e.g. P. phidias (Linnaeus, 1758) group of taxa), and Mysoria Watson, 1893. For example, Evans separated subspecies of Mysoria barcastus (Sepp, [1851]), in part, based on wing shape. For the Central American subspecies M. b. ambigua (Mabille \& Boullet, 1908), Evans (p. 67) noted that the "wings [are] not produced and termen H convex"; for the northern South American subspecies M. b. venezuelae (Scudder, 1872), he noted that "wings [are] more produced, termen H straight or excavate"; for the Guianan subspecies M. b. barcastus (p. 68), he noted that "wings [are] very produced"; and for the subspecies found south of the Amazon, M. b. barta Evans, 1951, he mentioned a "complete reversion to ambigua both in respect of wing shape and the width of the yellow border." Evans found significant varia- tion in the ventral hindwing colored marginal border in these taxa, and considered these differences to be informative. Considering the seasonal variation seen in Mexican Mysoria species (M. affinis and M. amra), it is suggested that a careful examination of the $M$. barcastus group (and other genera of Pyrrhopyginae) may reveal similar patterns of variation, which could justify some taxonomic changes.

Material examined. Mysoria affinis (209 males, 105 females), in addition to type material discussed above. In some cases, Municipality information was not listed on specimen labels, but has been added herein: Mexico, Chiapas: Mpio. Jiquipilla: Parque "El Aguacero", km 20, Cintalapa - Tuxtla Gutiérrez, 500 m, 23-IX-1978, Soberón leg. (1 male, MZFC); Mpio. La Trinitaria: Las Delicias, 11-X-1971, Welling leg. (1 male, 1 female, ADW); Colima: Mpio. Colima, Colima, 17-VI-1916, Hoffmann leg. (1 male, AMNH); 21-IX-1916, Hoffmann leg. (1 male, AMNH); Mpio. Comala: Comala, 12-IV-1967, Wind leg. (1 male, AMNH); Mpio. Manzanillo: El Salto, N of Cerro la Calera, 3-I-1996, Warren leg. (1 male, ADW); Pedro Núñez, N of La Central, 4-I-1996, Warren leg. (1 male, ADW); Punta de Agua de Camotlán, 2 km NE, 1-I-1996, Warren leg. (2 males, ADW); Mpio. Minatitlán: Platanarillos, 350 m, 29-IX-1994, MZFC (1 male, MZFC); Mpio. Tecoman: La Salada, 4-VI-1967, Wind leg. (2 males, AMNH); Mpio. Villa de Álvarez: Agua Dulce, 250 m, 27-IX-1994, MZFC (1 male, MZFC); 13-IV-1995, MZFC (1 male, MZFC); 11-XII-1995, Vargas \& Salinas leg. (2 females, MZFC); Guerrero: no locality, O.T. Baron leg. (3 males, DZUP- 


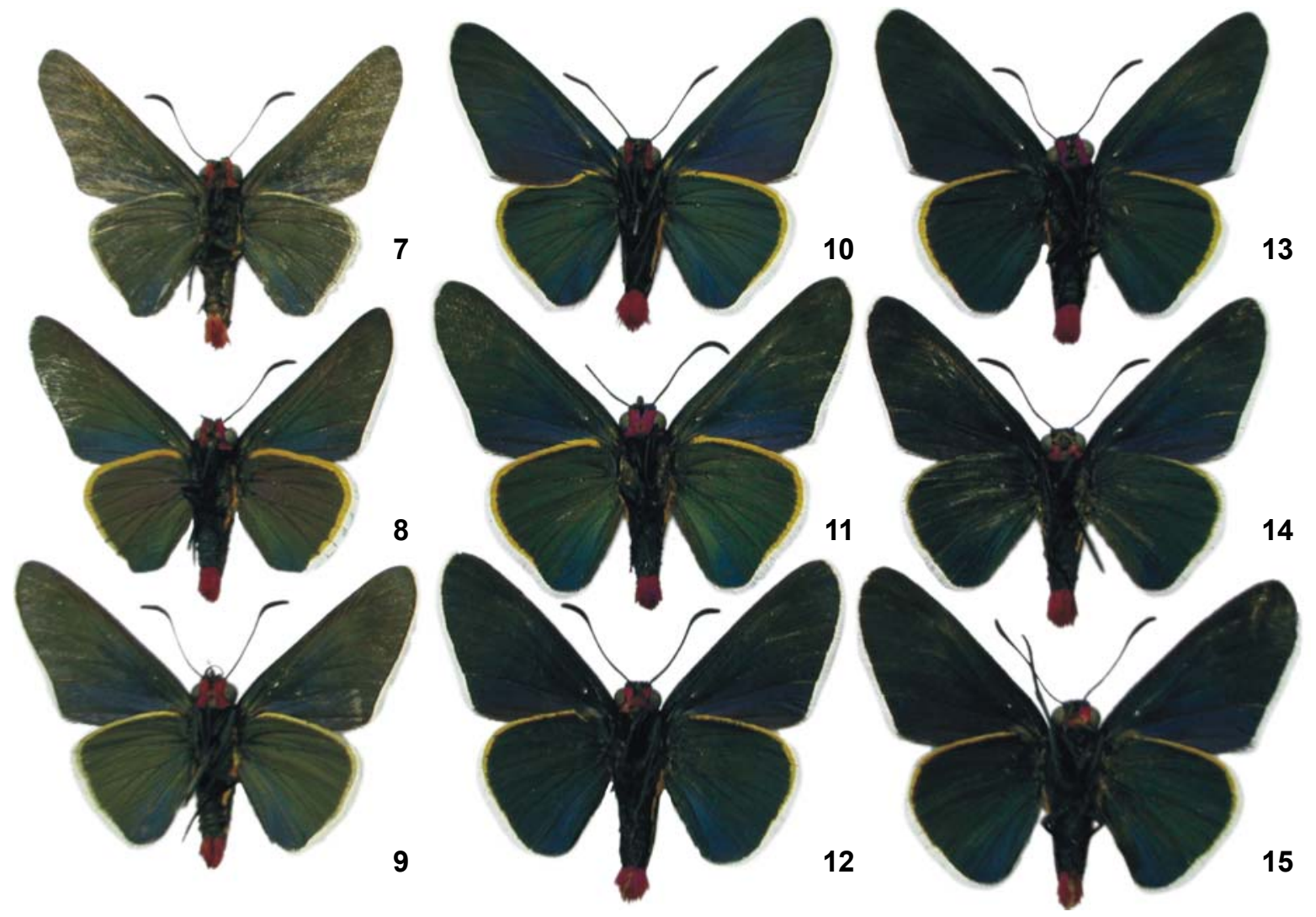

Figures 7-15. Continuum of variation seen in wing shape among Mysoria affinis males, ventral view: (7) Mexıco, Jalisco: Mpio. Autlán: Ahuacapán, 900 m, 7-VI-1994 A.D. Warren leg.; (8) Méxıco, Colima: Mpio. Villa de Álvarez: Agua Dulce, 13-IV-1995, MZFC crew; (9) Mexıco: Jalisco: Mpio. Autlán: Ahuacapán, 900 m, 7-VI-1994 A.D. Warren leg.; (10) Méxıco, Jalisco: Mpio. Autlán: Ahuacapán, 900 m, 7VI-1994 A.D. Warren leg.; (11) Mexıco: Colima: Mpio. Villa de Álvarez: Agua Dulce, 27-IX-1995, MZFC crew; (12) Méxıco, Michoacán: Mpio. Arteaga: Hwy. 37 at Rancho "El Zorrillo", 764 m, 20-IX-1995, L. González-Cota leg.; (13) Mexıco, Michoacán: Mpio. Gabriel Zamora: Barranca de Cóbano, 550 m, 24-IX-1994, L. González-Cota leg.; (14) Mexıco, Michoacán: Mpio. Gabriel Zamora: Barranca de Cóbano, 550 m, 31-VIII-1994, L. González-Cota leg. (15) Mexıco, Michoacán: Mpio. Arteaga: Hwy. 37 at Rancho "El Zorrillo", 764 m, 25-IX-1995, L. González-Cota leg.

OM); Mpio. Atoyac: Rincón de las Parotas, 300 m, 20-I-1987, MZFC (1 female, MZFC); Mpio. Tepecoacuilco de Trujano/ Zumpango del Río: Río Mezcala, IX-1935, Escalante leg. (1male, 1 female, DZUP-OM); Mpio. Zihuatanejo: Zihuatanejo, IX-1952, T. Escalante leg. (1 male, MZFC); 13-16-VII-1983, Vernon leg. (1 male, Vernon colln.); Jalisco: Mpio. Autlán: Ahuacapán, 900 m, 7-VI-1994, Warren leg. (10 males, 2 females, ADW); Mpio. La Huerta: Chamela Bay, 19-XI-1937, Rindge leg. (1 female, AMNH); 28-III-1939, Rindge leg. (1 male, AMNH); 14-XII-1939, Rindge leg. (1 male, AMNH); Mpio. Puerto Vallarta: Banderas Bay, 19-XI-1939, Rindge leg. (2 males, 1 female, AMNH); Mpio. unknown: Cihuatlan, IX-1948, Escalante leg. (1 female, AME); Michoacán: Mpio. Arteaga: Arteaga, 17-VI-1995, González leg. (1 male, MZFC); 5-VIII-1995, González leg. (1 female, MZFC); 6-VIII-1995, González leg. (1 female, MZFC); 29-VIII-1995,
González leg. (1 male, 1 female, MZFC); 4-IX-1995, González leg. (3 males, 2 females, MZFC); 13-IX-1995, González leg. (39 males, 24 females, MZFC); 14-IX-1995, González leg. (16 males, 5 females, MZFC); 17-IX-1995, González leg. (11 males, 6 females, MZFC); 18-IX-1995, González leg. (22 males, 4 females, MZFC); 19-IX-1995, González leg. (1 male, 1 female, MZFC); 22-IX-1995, González leg. (4 males, 3 females, MZFC); 27-IX1995, González leg. (1 male, MZFC); Las Juntas, 625 m, 27-XI1994, González leg. (2 females, MZFC); Hwy. 37 at Rancho "El Zorrillo", 764 m, 20-VI-1995, González leg. (1 male, MZFC); 24-VI-1995, González leg. (1 male, MZFC); 8-VII-1995, González leg. (1 male, 2 females, MZFC); 11-VII-1995, González leg. (1 male, MZFC); 13-VII-1995, González leg. (1 female, MZFC); 28VIII-1995, González leg. (1 male, MZFC); 31-VIII-1994, González leg. (1 female, MZFC); 31-VIII-1995, González leg. (1 male, 

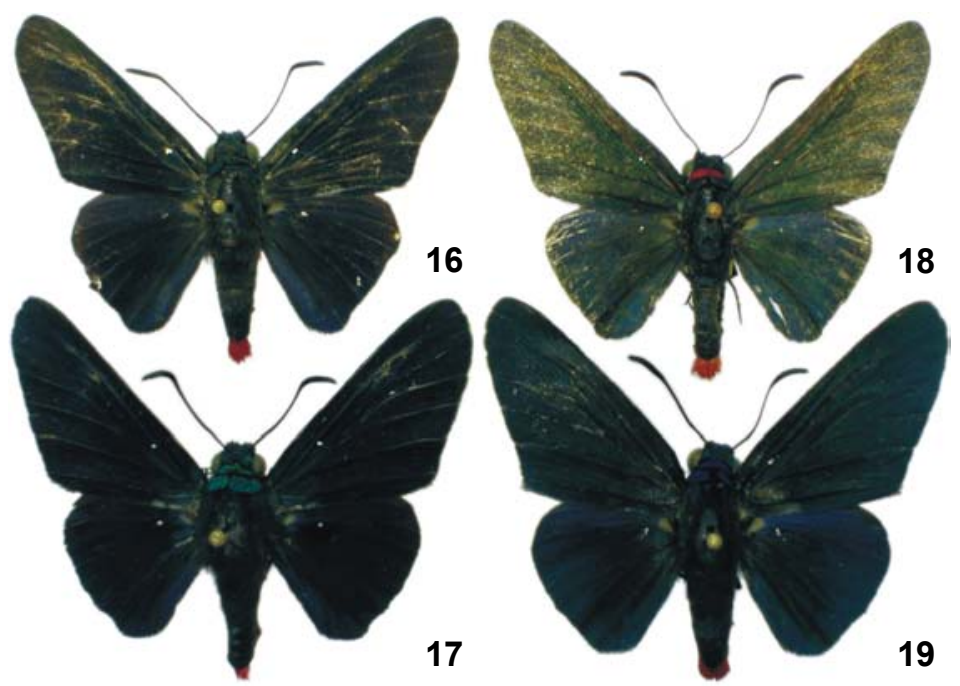

Figures 16-19. Males of Mysoria amra (left column) and M. affinis (right column), dorsal view, showing variation in wing width. Mysoria amra: (16) Mexıco, Jalisco: Mpio. Casimiro Castillo: La Calera, 650 m, 5-VI-1994, A.D. Warren leg.; (17) Mexıco, Nayarit: Mpio. Jalisco: El Refilion, 780 m, 2-X-1996, A.D. Warren leg. Mysoria affinis: (18) Mexıco, Jalisco: Mpio. Autlán: Ahuacapán, 900 m, 7-VI-1994 A.D. Warren leg.; (19) Mexıco, Michoacán: Mpio. Gabriel Zamora: Barranca de Cóbano, 550 m, 24-IX-1994, L. González-Cota leg.

MZFC); 2-IX-1995, González leg. (1 male, MZFC); 3-IX-1994, González leg. (1 female, MZFC); 3-IX-1995, González leg. (2 males, MZFC); 4-IX-1995, González leg. (2 females, MZFC); 5IX-1995, González leg. (1 male, MZFC); 6-IX-1995, González leg. (1 male, MZFC); 7-IX-1995, González leg. (1 male, MZFC); 8-IX-1995, González leg. (2 males, 2 females, MZFC); 16-IX1996, González leg. (1 female, MZFC); 18-IX-1995, González leg. (2 males, MZFC); 20-IX-1995, González leg. (2 males, MZFC); 21-IX-1995, González leg. (2 males, 1 female, MZFC); 22-IX1995, González leg. (1 male, 1 female, MZFC); 23-IX-1995, González leg. (4 males, 3 females, MZFC); 24-IX-1995, González leg. (1 male, MZFC); 25-IX-1995, González leg. (3 males, MZFC); 29-IX-1995, González leg. (3 males, MZFC); 30-IX-1995, González leg. (2 males, MZFC); 15-XI-1994, González leg. (1 female, MZFC); 18-XI-1994, González leg. (1 female, MZFC); 21-XI-1994, González leg. (1 female, MZFC); 28-XI-1994, González leg. (3 males, MZFC); Mpio. Coahuayana: San Telmo, Ojo de Agua, 8-14-VI-19??, González leg. (1 female, MZFC); Mpio. Gábriel Zamora: Barranca de Cóbano, 550 m, 12-I-1991, González leg. (1 female, MZFC); 25-VIII-1994, González leg. (1 male, 2 females, MZFC); 31-VIII-1994, González leg. (3 males, 4 females, MZFC); 11-IX-1994, González leg. (5 males, 4 females, MZFC); 24-IX-1994, González leg. (2 males, MZFC); 3-X-1993, González leg. (2 females, MZFC); 8-X-1989, González leg. (1 female, MZFC); P.H. Cupatitzio, 918 m, 28-IX-1994, González leg. (1 female, MZFC); 26-VIII-1997, Warren leg. (3 males, 1 female, ADW); Mpio. La Huacana: Presa Zicuirán, 300 m, 25VIII-1991, González leg. (1 male, MZFC); Mpio. Parácuaro: Parácuaro, 11-VI-1995, González leg. (1 male, 1 female, MZFC);
Nayarit: Mpio. Tepic, Tepic, IX-1964, Escalante leg. (4 males, 6 females, AMNH); OAXACA: Mpio. San Bartolo Yautepec/San Carlos Yautepec: 3 mi SE Río Hondo, 17-VII-1987, Kovarik \& Schaffner leg. (1 male, TAMU); Mpio. San Pedro Pochutla: Puerto Ángel, 16-II-1998 (1 male, ADW); 18-II-1998 (1 male, ADW); Mpio. Santa María Tlahuitoltepec: $8 \mathrm{~km} \mathrm{~N}$. Nejapa, 12-VIII1970, Steinhauser leg. (1 male, DZUP-OM); Puebla: Mpio. Matamoros, Jaulillas, 18-VIII-1968, Moral leg. (7 males, 2 females, DZUP-OM); Sinaloa: Mpio. Mazatlán: Mazatlán, no date, Hy. Edwards leg. (4 males, AMNH); 14-VI-1962, Rawson leg. (1 female, AME); 5-IX-1967, Welling leg. (1 male, 1 female, DZUPOM); 26-IX-1975, Weber leg. (1 male, DZUP-OM); State unknown: Mpio. La Cruz: Sabinal, 200 m, no date (1 female, DZUP-OM).

De la Maza (1987: pl. 58, fig. 15) illustrated a male $M$. affinis from Rancho Viejo, Morelos State, and also lists the species (p. 143) from San Nicolás Tolentino, México State. Evans (1951: 69) mentioned three specimens from "Guatemala"; as far as is known, these are the only reported specimens of $M$. affinis from outside of Mexico.

\section{ACKNOWLEDGMENTS}

The junior author thanks CNPq (Conselho Nacional de Desenvolvimento Científico e Tecnológico) for providing a research fellowship, and the senior author thanks the United States National Science Foundation (Doctoral Dissertation Improvement Grant), which provided funds to travel to Brazil in February and March of 2004. We thank the curators of various museums who have allowed us to examine specimens un- 
der their care: Hans-Joachim Hannemann (curator in 1979 of Lepidoptera at the "Museum für Naturkunde der Humboldt Universität", Berlin, Germany), Jim Miller and Fred Rindge (American Museum of Natural History, New York), Lee D. and Jacqueline Y. Miller (Allyn Museum of Entomology), and Ed Riley (Texas A \& M University). We especially thank Jorge Llorente-Bousquets, Armando Luis-Martínez and Isabel VargasFernández (Museo de Zoología, UNAM, Mexico City) for arranging collecting permits and enabling the study of material cited herein, and Lamberto González-Cota (Uruapan, Michoacán) for his hospitality to the senior author during August, 1997. We would also like to thank the late H. A. Freeman for sharing specimens and information related to this paper. We also thank Dr. Gerardo Lamas, Museo de Historia Natural, Lima, Peru, and an anonymous reviewer, for reviewing this paper and making valuable suggestions.

\section{REFERENCES}

Austin, G. T. \& A. D. Warren. 2002. Taxonomic notes on some Neotropical skippers (Lepidoptera: Hesperiidae): Pyrrhopyginae and Pyrginae. Dugesiana, Guadalajara, 9(2):15-49.

Burns, J. M. \& D. H. Janzen. 2001. Biodiversity of Pyrrhopygine skipper butterflies (Hesperiidae) in the Area de Conservación de Guanacaste, Costa Rica. Journal of the Lepidopterists' Society, Los Angeles, 55(1):15-43.

Evans, W.H. 1951. A Catalogue of the American Hesperiidae indicating the classification and nomenclature adopted in the British Museum (Natural History). Part I. Pyrrhopyginae. London, British Museum (Natural History). X+92p.

Freeman, H.A. 1969. Records, new species, and a new genus of Hesperiidae from Mexico. Journal of the Lepidopterists' Society, New Haven, 23(suppl. 2):1-62.

Godman, F.D. \& O. SAlvin. 1879-1901. Biologia Centrali-Americana. Insecta, Lepidoptera-Rhopalocera. Vols. II, III. London, Dulau \& Co., Bernard Quaritch, 782pp., 112 pls.

HerRich- SCHÄFFER, G.A.W. 1864-1871. Prodromus systematis lepidopterorum. Versuch einer systematischen Anordnung der Schmetterlinge. Correspondenz-Blatt zoologischmineralogischen Vereines in Regensburg 18 (7/8): 89-112, (9): 123-136, (10): 148-152 (1864); (11/12): 173-181 (1865); 19 (5): 63-76, (6): 84-92, (7): 100-108 (1865); 21 (9): 100106, (10): 124-128, (11): 138-144, (12): 161-172 (1867); 22 (8/9): 119-138, (11): 172-176 (1868); 23 (4): 56-64, (5): 6777, (9): 130-141, (11): 163-172, (12): 184-204 (1869); 24 (9/

Received in 26.III.2004; accepted in 31.V.2004.
10): 154-160 (1871); 25 (6/7): 103-104 (1871).

Llorente-Bousquets, J. E., A. Luis-Martínez \& I. Vargas-Fernández. 1990. Catalogo sistematico de los Hesperioidea de Mexico. Publicaciones Especiales del Museo de Zoologia, Mexico, 1:[iv], 1-70.

Luis-Martínez A., J.E. Llorente, I.F. Vargas \& A.D. Warren. 2003. Biodiversity and biogeography of Mexican butterflies (Lepidoptera: Papilionoidea and Hesperioidea). Proceedings of the Entomological Society of Washington, Washington, 105 (1): 209-224.

Maza Ramírez, R. DE LA. 1987. Mariposas Mexicanas. Mexico City, Fondo de Cultura Económica, 302p.

Maza, J. de LA; A.L. White \& R.G. de la MaZa E. 1991. La fauna de mariposas de México. Part II. Hesperioidea (Lepidoptera: Rhopalocera). Revista de la Sociedad Mexicana de Lepidopterología, Mexico City, 14 (1): 3-44.

MielKe, O.H.H. 2001. Estudo cladístico e descrições de tribos em Pyrrhopyginae (Lepidoptera, Hesperiidae). Revista Brasilera de Zoologia, Curitiba, 18(3):897-905.

- 2002. Pyrrhopyginae: gêneros novos e revalidados (Lepidoptera, Hesperiidae). Revista Brasilera de Zoologia, Curitiba, 19 (1): 217-228. - (in press) Hesperiidae, in: G. Lamas (Ed.). Checklist: Part 4A. Hesperioidea - Papilionoidea, in: J.B. Heppner (Ed.). Atlas of Neotropical Lepidoptera. Gainesville, Scientific Publishers.

MielKe, O.H.H. \& M.M. Casagrande. 2002. Notas taxonômicas em Hesperiidae neotropicais, com descrições de novos taxa (Lepidoptera). Revista Brasilera de Zoologia, Curitiba, 19(Supl. 1):27-76.

Vargas-Fernández, I., A. Luis-Martínez, J.E. Llorente-Bousquets \& A.D. WarRen. 1996. Butterflies of the State of Jalisco, Mexico. Journal of the Lepidopterists' Society, Los Angeles, 50 (2): 97-138.

Warren, A.D. 2000. Hesperioidea (Lepidoptera), pp. 535-580, in: Llorente-Bousquets, J.E., E. GonzÁlez Soriano \& N. Papavero (Eds). Biodiversidad, Taxonomía y Biogeografía de Artrópodos de México: Hacia una Síntesis de su Conocimiento. Volumen II. Mexico City, Universidad Nacional Autónoma de México, XVI+676p.

Warren, A.D.; I. Vargas-Fernández; A. Luis-Martínez \& J.E. LLORENTE-Bousquets. 1998. Butterflies of the State of Colima, Mexico. Journal of the Lepidopterists' Society, Los Angeles, 52 (1): 32-64. 